WellBeing International

WBI Studies Repository

1985

\title{
Human Perceptions of Animals and Animal Awareness: The Cultural Dimension
}

Elizabeth A. Lawrence

Tufts University

Follow this and additional works at: https://www.wellbeingintlstudiesrepository.org/acwp_sata

Part of the Animal Studies Commons, Ethics and Political Philosophy Commons, and the Other Anthropology Commons

\section{Recommended Citation}

Lawrence, E.A. (1985). Human perceptions of animals and animal awareness: The cultural dimension. In M.W. Fox \& L.D. Mickley (Eds.), Advances in animal welfare science 1985/86 (pp. 285-295). Washington, DC: The Humane Society of the United States.

This material is brought to you for free and open access by WellBeing International. It has been accepted for inclusion by an authorized administrator of the WBI Studies Repository. For more information, please contact wbisr-info@wellbeingintl.org.

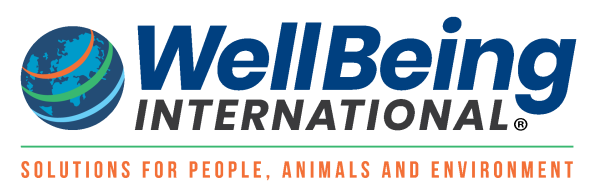




\section{HUMAN PERCEPTIONS OF ANIMALS AND ANIMAL AWARENESS: THE CULTURAL DIMENSION*}

\section{Elizabeth A. Lawrence}

Tufts University

School of Veterinary Medicine

Boston, MA. 02111

\section{Introductory Overview}

Culture is generally a powerful determinant of human perceptions of animals and the treatment animals receive in a given society. For example, Plains Indians' views of the status of animals-their capacities, their awareness, and their place in the world relative to mankind-differ radically from those characteristic of Western thought. Many of the contemporary Crow Indians, a group of native Americans among which I have recently carried out anthropological field research, continue to look upon their horses according to traditional tribal belief. Their particular attitude toward horses conflicts with that of the dominant white society with which the Indians and their horses must interact. Mutual hostility results from a lack of understanding between members of the two cultures who, though living in proximity, remain worlds apart in ethos. Two other examples from ethnographic literature involving the habitual treatment of mules in a community of farmers and of sled dogs by a group of Eskimos also highlight the importance of cultural attitudes in affecting interactions with animals in those societies. It is vital to strive to understand the many complex factors which determine views toward animals, including their capacities for awareness, in alien cultures whose value-systems may be foreign to our

\footnotetext{
* Paper presented at the Institute for the Study of Animal Problems Symposium on Animal Awareness and Human Perceptions: Implications for Animal Welfare, November 3, 1982.
} 
own. Since human actions toward animals are rooted in perceptual concepts concerming the intrinsic nature of those animals, it is only through empathy resulting from understanding such concepts that a beginning can be made in solving the many problems involved in human relationships with animals.

\title{
Plains Indian Worldview
}

\author{
See, Brothers; Spring is here. \\ The earth has taken the embrace \\ of the Sun, and soon we shall see \\ The children of all that love. \\ All seeds are awake, and all animals. \\ From this great power we too have our lives. \\ And therefore we concede \\ to our fellow creatures \\ even our animal fellows, \\ The same rights as ourselves \\ To live on this earth.
}

(Fuchs and Havighurst 1972, p. xv)

Speaking these words in 1877, the great Sioux leader, Sitting Bull, was expressing the viewpoint of his Plains Indian culture and society toward animals. Embodying a holistic concept of all creation, this outlook is at opposite poles from that of the white Anglo-American ethos which was aggressive and exploitative toward nature - the attitude characteristic of the dominant society which had all but defeated and subjugated the Plains tribes, even as Sitting Bull spoke. For in the minds of the whites, nothing could stand in the way of westward expansion and the progress of "civilization": Indians and nature were both considered as part of the wild which must be cleared away.

Plains tribes generally embrace a mode of thought in which all forms of life on earth exist on a dynamic circular plane. One form of life is not considered to be above another, in a linear hierarchy with man at the top, as in the Judaeo-Christian scheme. As one articulate native American expresses it, "All of life is living-that is, dynamic and aware, partaking, as it does, in the life of the All-Spirit, and contributing, as it does, to the ongoing life of that same Great Mystery" (Allen 1975). There is essential harmony in the world, and primary assumptions are that all of nature, both animals and people, "are seen to be brothers or relatives, all are offspring of the Great Mystery, children of our mother, and necessary parts of an ordered, balanced, and living whole." Such an ideology makes no separation between nature 
and mankind and no dualistic division between material and spiritual: all are expressions of the same reality (Allen 1975).

No people have been more closely attuned to the earth and to nature than have the nomadic tribes of the Great Plains, and their beliefs developed out of keen observations of their living environment. It was clear to them that other animals besides man possessed many capacities. People could see that animals had certain powers and believed that it was reasonable that they could think and communicate. Sitting Bull related how as a boy he was saved from the attack of a grizzly bear by the warnings of a meadowlark. The alert songbird had been aware of the boy's danger and communicated it. Thereafter, this bird, along with others of its kind, became Sitting Bull's special protector, whose speech he could henceforth understand (Vestal 1932). Such occurrences were by no means uncommon, and even today some individuals who still follow old traditions continue to experience them.

Native American creation tales, differing radically from Genesis, reveal insights about the status of animals as perceived by Indians. Unlike the Judaeo-Christian God, who made everything and then gave commandments as to the way it all was to function, the Cheyenne All-Spirit, for example, consulted the animals concerning the process of creation, once it had begun (Allen 1975). In virtually every native explanation for the beginning of the earth or the origin of the first human beings, feelings of close kinship with animals and great respect for other creatures and their powers are evident. In some versions, water birds were asked to dive down and bring up mud to form the earth (Burland 1970). Often the human race is believed to have come into existence with the aid of animals or through transformation from an animal (Emerson 1965). Certain tribes assert that mankind resulted from the union of two different species of animals, such as the snail and the beaver who were parents to the first Osage people (Marriott and Rachlin 1975).

\section{Crow Indians and Horses}

Today, although acculturation to the dominant society has brought many changes for native Americans, there are still some groups which have managed to retain much of their own culture. One of these is the Crow tribe of southeastern Montana, a Plains people among whom I have carried out field work (1975-80) focusing on attitudes toward nature and animals. A large majority of the Crows still speak their native language, and many tribespeople have retained traditional beliefs, customs, and ceremonies. One aspect of the Crow attitude toward animals - that of their relationship with their horses-illustrates the relevance of the 
cultural dimension in affecting perceptions of animals and their treatment. Crow interaction with horses, I found, exemplifies the sharp contrasts which exist between the Crow ethos and the views of the members of the dominant white society who live on or near the reservation and with whom the Indians and their livestock must interact.

Horses are very important to contemporary Crows, and are abundant today on the reservation. The vital significance of horses in the lives of these people results from a combination of factors from the past and from the present. For Plains tribes such as the Crows, acquisition of horses early in the eighteenth century vastly improved the quality of their lives in virtually every way. Horses revolutionized transportation, hunting, and war, and the many benefits they conferred upon their riders soon made the animals the tribe's most treasured possessions. So great was their worth that they became the measure of all value, synonymous with prestige and wealth. Yet this did not mean, as it might have in another context, that the relationship with horses was purely utilitarian. As admired partners, horses became part of the human spiritual and aesthetic spheres as well as the pragmatic. Horses imparted special knowledge and power to people who established rapport with them, and could provide help in time of trouble. A strong sense of reciprocity supported the belief, still widely held, that considerate treatment of horses brings good fortune to a person and that mistreatment of the animals will be punished. Traditional taboos, originating out of gratitude, continue to dictate against killing horses and eating their flesh. Plains riders became as one with their mounts, and communication based on mutual understanding was a natural occurrence. As the great Crow chief, Plenty Coups, expressed it:

My horse fights with me and fasts with me, because if he is to carry me in battle he must know my heart and I must know his or we shall never become brothers. I have been told that the white man, who is almost a god, and yet a great fool, does not believe that the horse has a spirit (soul). This cannot be true. I have many times seen my horse's soul in his eyes. And on this day on that knoll I knew my horse understood. I saw his soul in his eyes. (Linderman 1930, p. 100)

One of the most tragic aspects of the Plains natives' experience after they were confined to reservations was the cessation of active participation in the horse-related activities which had made life meaningful as mounted nomads. For the Crows, adverse reaction to this loss was a significant factor contributing to the difficult adjustment to a sedentary 
existence. It is the period of their tribal history between the introduction of the horse and the end of nomadic life by which Plains Indians are still characterized, even by the natives themselves. Today the Crows continue to look back to the Horse Era of their history with nostalgia and enduring pride. Partnership with horses had given their people new freedom and dignity, and their dynamic interactions with these animals charged the tempo of life with the force of expanded dimensions of experience and awareness.

In recent times, the Crows were fortunate in being able to bring about a return of horses to their reservation. Renewed interest in them has meant that horses have been adapted to recreational activities compatible with modern reservation life. For many Crows, association with their horses is essential to the maintenance of their identity as Indians. Horses, though, do not have to be ridden or handled individually to be important. Repeatedly, the Crow people made clear their deep satisfaction in simply having abundant horses grazing around them. This is perceived as the way life should be for Crows, who told me "horses are part of our nature, and love of horses is instilled into the spiritual makeup of all Crows from the time they are little." They reveal that the satisfaction derived from the prevalence of horses on tribal lands is a source of encouragement in facing the difficult problems of daily existence which natives feel are imposed upon them by the dominant white society.

Despite the vital importance of interaction with horses in contemporary Crow society, however, the role of the animals is not understood by local non-Indians and officials who deal with the Indians and their horses. Such people, lacking empathy, generally view animal relationships only by standards set by their own culture and the values it espouses. Whites claim, for example, that the Crows are negligent in allowing their horses to overgraze the land, that they should fence in their livestock, and control their animals at all times. But the Crows, with their enculturation from a nomadic background, do not have the same sense of "management" of animals and the manipulation of nature that are ingrained in the Western ethos. Thus differing points of view cause frequent conflicts. Neighboring whites often criticize the Crows for what non-Indians perceive as cruelty to their horses. The traditional practice of leaving horses to "winter out" in the northern Montana Plains without providing shelter or supplementary feed brings accusations of inhumanity and neglect. But the Crows' perceptions of animals and their capacities are different. Crows know that a horse will paw through the snow to eat the grass below, just as in the old nomadic days, and that this ability shows intelligence and adaptiveness. Tribesmen recall that throughout Crow history cottonwood bark served as winter feed for horses on the Northern Plains. The efficacy of this practice in keeping horses well-nourished all winter has been documented (Boller 1972). 
Crow horsemen insist that horses left out to fend for themselves are usually in far better condition in the spring than those which have been sheltered and provided with artificial feed. The intense pride these people take in their horses' toughness reveals the Crows' sense of identification with their animals and their concept that animals are not creatures of another order, but close kin. Crows today feel that even though their fellow tribesmen may be losing their former physical strength and endurance by succumbing to a "soft" life on the reservation, at least their horsestheir "other selves," as it were-are perpetuating the hardiness which was formerly necessary to sustain life on the Plains. Indeed, the Crows' own historic ability to survive, surrounded as they once were by powerful enemies, and later to endure white domination while retaining much of their culture, has come to be symbolized by the hardihood of their horses.

This idea about wintering of horses is expressed in the story told to me by a Crow who in his boyhood had observed the governmentorganized killing of so-called "worthless range horses" on tribal land. He made special reference, again and again, to the fact that all the horses had been shot indiscriminately, not just the weakest or the "locoed" ones (poisoned by eating loco weed), as the official horse-killers had claimed. Equine victims of the slaughter included, he stressed, "the horses that could winter by themselves and survive alone." His words echoed disbelief as he reiterated his feelings about what was to him a preposterous aspect of the horse slaughter. "Many that were killed were hardy, and needed no care in a hard winter. Those horses knew what to do. They could make it themselves, on their own. But even the horses who were used to the hard winter were killed off with the rest!"

Winter care of equine animals is directly related to religion in the minds of many with whom I spoke. Crow elders explained that one of the reasons such great supernatural powers are ascribed to animals in their traditional belief system is that "they can get along alone, unaided, without clothing, shelter, and without fire." This remarkable ability distinguishes nonhuman creatures from mankind, who requires these artificial elements for survival, and helps to explain the animals' roles as intermediaries with the Great One. "There is power vested in animals," Crow traditionalists say, "because they can survive with no contribution from man." Thus, what constitutes "cruel treatment" in the minds of whites is for the Crows a sign of deep admiration for their horses' physical endurance and special mental and spiritual endowments. In this important matter concerning animal abilities, human perceptions resulting from cultural differences act to preserve social distance between two peoples who live in proximity and yet are worlds apart.

It must be emphasized that along with considering the particular ethos by which a society views its animals, it is essential that peoples' 
standards for treatment of animals be considered in the light of the standards they set for themselves. Without considering this comparative dimension, a distorted picture emerges. Life in the Great Plains, the context in which Crow culture developed, for example, was demanding. Strength and endurance, above all, were required and merited society's approval - no less for animals than for people.

\section{Mules as Victims}

Turning now to a different society for a brief comparison, a study of tenant farmers in the Deep South as described by James Agee in his classic work, Let Us Now Praise Famous Men (1978), provides an intimate portrait of a culturally distinct group of people living in extreme poverty. Probably lost upon the average reader within the vast welter of information the writer gives about every observable detail of life for these downtrodden people, are a few remarkably revealing passages about the treatment of the mules who work with the sharecroppers. "Even in harnessing him his head is knocked around some, and in all his motions relevant to his users he is used with the gratuitous sort of toughness an American policeman uses against anyone (except the right people) who happen to fall into his power" (Agee 1978). "The farmer," Agee goes on to say, "is liable to be an expert within the whole range of bullying, battering, and torturing this particular animal, and to have peculiarly urgent egoistic and sexual needs to exert full violence and domination over something living, preferably something at least as large and strong as himself" (1978).

With insight, Agee explains that "the mule stands readier victim than any other animal because he is used in the main and most hopeless work, because he is an immediate symbol of this work, and because by transference he is the farmer himself (italics mine), and in the long tandem harness wherein members and forces of a whole world beat and use and drive and force each other, if they are to live at all, is the one creature in front of this farmer" (1978). The writer confesses his own lack of ability to fully explain the observed sadism, the "casualness, apathy, self-interest, unconscious, offhand, and deliberated cruelty, in relation toward extra-human life" which is "terrible enough to freeze your blood or to break your heart or to propel you toward murder." Sadly, he concludes that it is "unlikely that enough of the causes can ever be altered, or pressures withdrawn, to make much difference" (1978).

Unfortunately for purposes of analysis, the sharecroppers Agee observed so closely never told him of their perceptions of animals or of animal awareness. It is clear, however, that in their life stories there is revealed no sense of reciprocity or kinship with their fellow creatures, no belief in a harmonious world. The explanation that the almost unbearable 
hardship of their own lives bears directly upon the sharecroppers' treatment of animals is inescapable. The sense of identity with his mules which Agee noted on the part of the farmer must be a powerful determinant. Related to this is the awful and unspoken truth that if awareness were not somehow attributed to the mules, such abuse as they received would yield no satisfaction to the drivers. This is one of the dilemmas in attempting to understand the roots of cruelty: do the perpetrators lack empathy, or do they indeed have it in excess, torturing in fact because they do have sharpened cognizance of the pain they inflict? Undoubtedly, many causative factors are involved in the dynamic relationship between sharecropper and mule which habitually results in the beast as victim of human brutality. A vitally important element here, as in the next example of sled dogs, is that such relationships are deeply ingrained, having the full force and endorsement of societal and cultural sanction. One carries out actions toward animals not just as an individual who is so disposed, but is motivated, at least in part, by a strong sense of belonging to a group which shares and upholds this particular mode of behavior.

\section{Treatment of Sled Dogs}

Sled dogs among arctic peoples are invariably described by observers as, according to our standards, inhumanely handled and often cruelly abused. In my experience the comment routinely following any discussion of this matter is that such treatment is inevitable, since it is not feasible to make "pets" out of working animals. Yet the whole question of the necessity for such harshness actually remains unanswered. Once again, there is a lack of data on native belief concerning their dogs' awareness. What is known is that in interaction with sled dogs, reciprocal kindliness and devotion between man and animal, whatever their untested effects may be, generally do not have the sanction of Eskimo societies that have so far been studied. Whether this attitude toward dogs has its origin, as some would say, in pure utility, or whether it results from a more complex combination of deep-level psychological and sociological characteristics of the Eskimo ethos has yet to be explained.

Resulting from her intensive long-term field research in the Canadian arctic, Jean Briggs' remarkably detailed ethnography, probes virtually every aspect of the Eskimo group with whom she lived. Expressively titled Never in Anger (1972), the study lays bare the central characteristic which ensures social cohesion in a difficult environment: individuals must never express or show outward signs of anger toward other people. Repressed hostility may be one cause, then, of the sadistic treatment of animals. Briggs describes the children's delight in killing the unwanted 
newborn puppies, "dashing them with squeals of excited laughter against boulders or throwing them off the high knoll edge into the rapids below" (1972). It is clear that this behavior is not just an individual affair; the practice has social approval, cultural acceptance. "Killing puppies was a child's job." One youngster, "her eyes gleaming with pleasure, beat two small puppies with a stick until they cried piteously." Her mother paid no attention (Briggs 1972). Another child "squeezed a longspur (small bird) until its heart burst through its skin" (1972). Significantly, one particular Eskimo woman, the object of derision and virtual social ostracism because of her many atypical and unconforming behavior patterns, was the only person observed by the anthropologist who "rolled on the ground playfully with the puppies" (Briggs 1972).

\section{Discussion}

Answers to the dilemmas posed by the above examples and many more which could be cited are, unfortunately, difficult to find. Scholars must search, and probe ever more deeply, in an attempt to shed light on the complexities involved in human interactions with animals. Although there is no one solution, it is essential to realize that culture, as a vital force in people's lives, must be recognized as a powerful determinant of patterns in the treatment of animals, as in other dimensions of human experience. "It's that kind of world here" is an expression Crows frequently use in describing their lives and beliefs. They are speaking not only of the outer world of interactions, but of the inner world of attitudes as well. Where cultural perceptions determine that animals and people share many important qualities and can cooperate and communicate, it follows that the treatment of animals generally is based on respect. In human-animal interactions, the degree of awareness attributed to the beasts works in dynamic equilibrium: the more an animal is downgraded as an object whose worth is measured only by usefulness to mankind, the less it is possible for that animal to have meaningful input into a relationship with people. Whatever potential it has, like that of an abused child reared in a closet, can never be realized.

One feature in a society's ethos which I have found to play a particularly significant role in determine relationships to animals is the aesthetic element. In communicating with informants of different cultures about their perceptions and treatment of animals, I have found that if appreciation for the beauty and uniqueness of the animal is lacking, treatment is less humane. Possession of beauty in its deepest dimension implies individual worth beyond what is central to human concerns. Like all of us who have thought long and hard about such questions, James Agee, in the book referred to earlier, wonders about the human 
"sense of beauty," asking "is this an 'instinct' or a product of "training"” (1978). Portraying the poverty-stricken sharecroppers of his study with compassion, and finding them beautiful to him, he nonetheless admits that the people themselves are totally without a sense of beauty. Questioning whether this lack is due to the necessity of overwork leading to the exclusion of all that is not pragmatic, their poverty, their living only among "man-built things," or their low social status, Agee is unable to give a satisfactory answer. He goes on, however, to provide a remarkable observation about animals: "It is very possible, I would believe probable, that many animals are sensitive to beauty in terms of exhilaration or fear or courting or lust; many are, for that matter, accomplished and obvious narcists [sic]: in this sense I would also guess that the animals are better equipped than the human beings" (1978). More than through any other mechanism it appears that by means of culturally-defined perceptions of animals as intrinsically beautiful and valuable, and as possessing significant shared capacities including awareness, that we come to grant to animals, as the Plains Indians did, "the same right as ourselves to live on this earth." 


\section{References}

Agee, J. and Evans, W. 1978. (1st ed. 1939) Let Us Now Praise Famous Men. New York: Ballantine Books. pp. 193, 194, 285, 286.

Allen, P.G. 1975. The Sacred Hoop: A Contemporary Indian Perspective on American Indian Literature. In: Chapman, A. ed. Literature of the American Indians: Views and Interpretations. New York: New American Library. pp.111-35.

Boller, H.A. 1972 (1st ed. 1867) Among the Indians: Four Years in the Upper Missouri, 1858-1862. Lincoln, Nebraska: University of Nebraska Press. pp. 204-5.

Briggs, J.L. 1972. (1st ed. 1970) Never in Anger. Cambridge, Massachusetts: Harvard University Press. p. 174.

Burland, C. 1970. (1st ed. 1965) North American Indian Mythology. New York: Hamlyn House. p. 69.

Emerson, E.R. 1965. (1st ed. 1884) Indian Myths. Minneapolis, Minnesota: Ross and Haines, Inc. p. 127.

Fuchs, E. and Havighurst, R.J. 1972. To Live on This Earth. Garden City, N.Y.: Doubleday and $\mathrm{Co}$.

Linderman, F.B. 1970. (1st ed. 1930) Plenty-Coups: Chief of the Crows. New York: John Day Co.

Marriott, A. and Rachlin, C.K. 1975. Plains Indian Mythology. New York: Thomas Y. Crowell Co. p. 24.

Vestal, S. 1932. Sitting Bull: Champion of the Sioux. Boston: Houghton Mifflin Co. p. 21-22. 